\title{
Geological Society of London Engineering Group Working Party on Periglacial and Glacial Engineering Geology
}

\author{
David Giles, Martin Culshaw, Laurance Donnelly, David Evans, Mike de \\ Freitas, James Griffiths, Sven Lukas, Christopher Martin, Anna Morley, \\ Julian Murton, David Norbury, Mike Winter
}

Geological Society of London, Burlington House, Piccadilly, London, W1J 0BG, UK.

In 2012 the Engineering Group of the Geological Society of London established a Working Party to undertake a state-of-the-art review on the ground conditions associated with former Quaternary periglacial and glacial environments and their materials, from an engineering geological viewpoint. The final report was not intended to define the geographic extent of former periglacial and glacial environments around the world but to concentrate on ground models that would be applicable to support the engineering geological practitioner. Key aspects of ground condition uncertainty would be addressed and developed within these ground models.

The Working Party considered the following topics with respect to engineering geology: Quaternary Setting, Geomorphological Framework, Glacial Conceptual Ground Models, Periglacial Conceptual Ground Models, Engineering Materials and Hazards, Engineering Investigation and Assessment along with Design and Construction Considerations.

Keywords Glacial, Periglacial, Ground Model, Quaternary.

\section{Introduction}

In 2012 the Engineering Group of the Geological Society of London established a Working Party to undertake a state-of-the-art review of ground conditions associated with former Quaternary periglacial and glacial environments and their materials, from an engineering geological viewpoint. The final report will concentrate on the development of new ground models that would be applicable to support the engineering geological practitioner, enhancing current knowledge, whilst focusing on their applicability to the engineering geologist. The ground models will be developed to communicate the complex and variable ground conditions that could be expected in these former periglaciated and glaciated terrains. The Working Party 
considered the following topics with respect to engineering geology: Quaternary Setting, Geomorphological Framework, Glacial Conceptual Ground Models, Periglacial Conceptual Ground Models, Engineering Materials and Hazards, Engineering Investigation and Assessment along with Design and Construction Considerations. Former glacial and periglacial settings present the engineering geologist with a complexity of vertically and laterally varying ground conditions with a high degree of uncertainty which require the use of conceptual ground models to fully understand and interpret, for example the complexities of the ice-marginal environment as conceptualized in Figure 1. Such complexity can also be seen in Figure 2 , an example of the varying ground conditions associated with superficial valley disturbances in a former clay pit in Devon, UK.

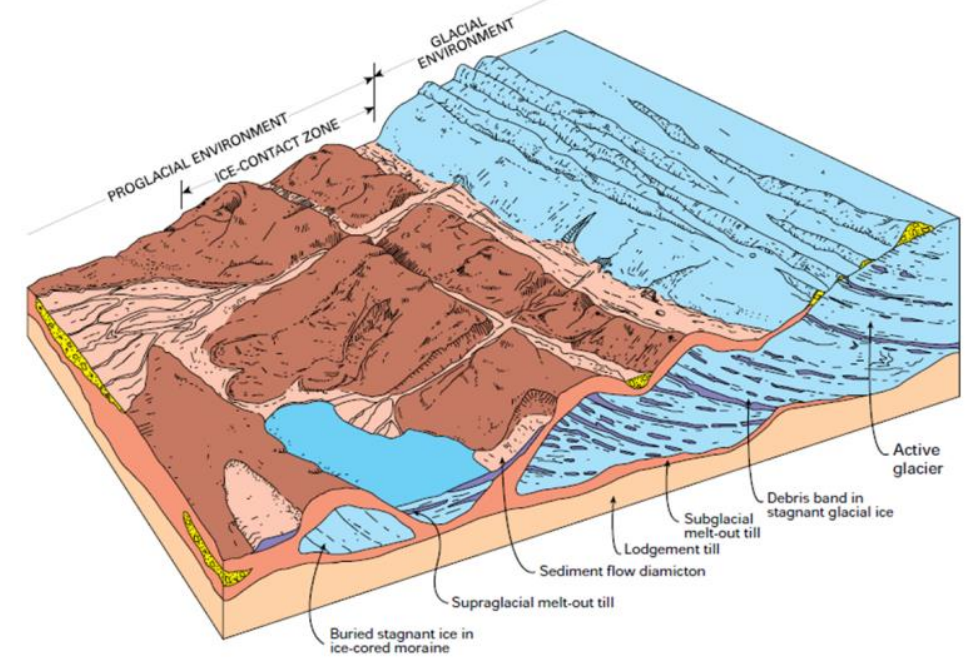

Fig. 1 Current supraglacial and ice-contact ground model (McMillan \& Powell, 1999).

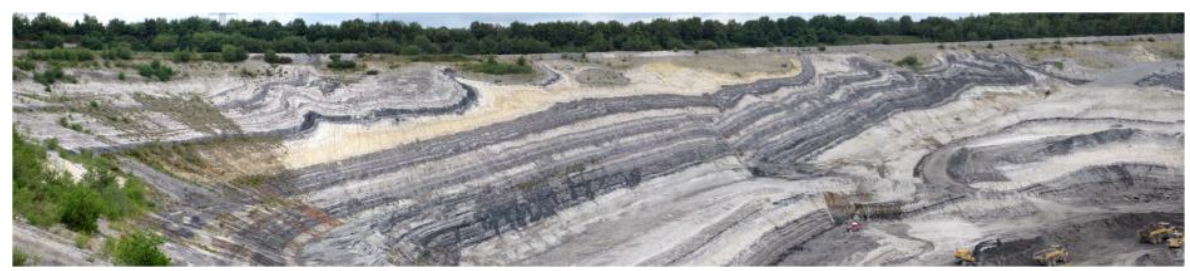

Fig 2. Periglacial environment: Superficial valley disturbances, Newbridge Ball Clay Quarry, Devon, UK. (Dump trucks in bottom right corner for scale). 


\section{Terms of Reference}

The Periglacial \& Glacial Engineering Geology Working Party (PGEGWP) has been established by the Engineering Group of the Geological Society and comprises officers and specialist participating members who will act as lead authors. The PGEGWP will produce a report, in book format, to complement the previous report on Tropical Residual Soils produced by an earlier Working Party of the Engineering Group, first published in 1990 and republished in book format in 1997 (Fookes, 1997). A similar format was adopted by the Hot Deserts Working Party, which published their final report in 2012 (Walker, 2012). It is intended that the report will be a state-of-the-art review on the ground conditions associated with former Quaternary periglacial and glacial environments and their materials, from an engineering geological viewpoint. There necessarily will be appropriate coverage of the modern processes and environments that formed these materials. A key aspect of the report will be to integrate soil description methodologies utilized by Quaternary scientists, engineering geologists and geotechnical engineers. Field workshops have been organized (Fig. 3 and Fig. 4) to consider various glaciogenic classification schemes specifically with their regard to their applicability to engineering geology.

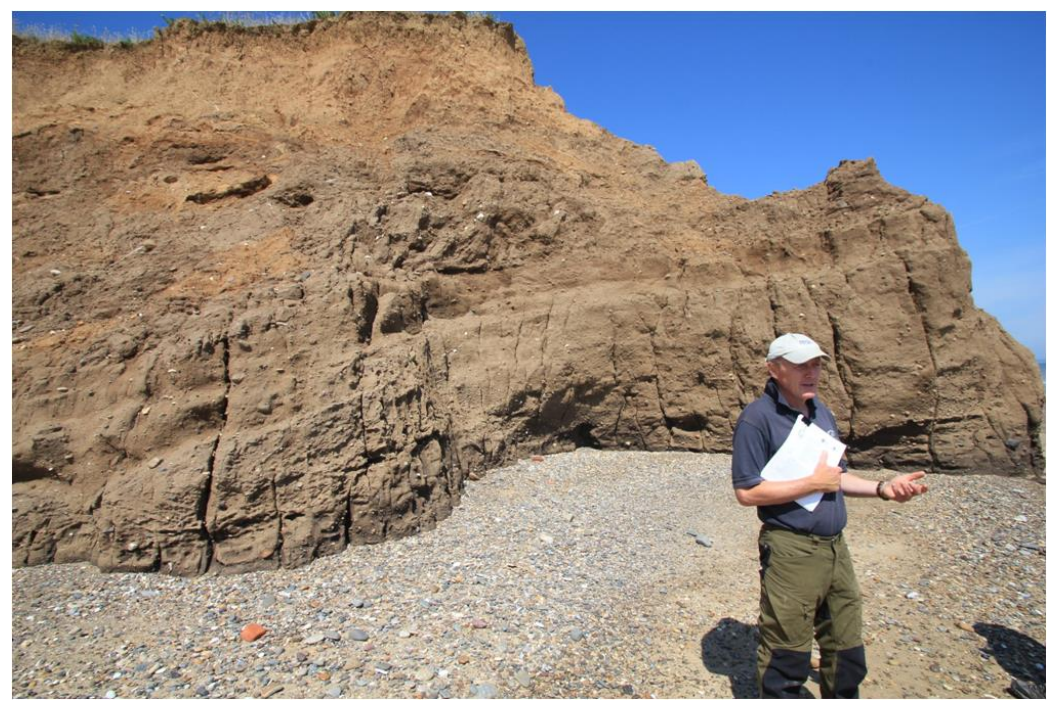

Fig. 3 Working Party field discussion of glaciogenic soil classification and description methodologies at Barmston, East Yorkshire, UK. Section shows Skipsea Till overlain by subglacial canal fills.

It is not intended to define the geographic extent of former periglacial and glacial environments around the world, but to concentrate on ground models that would 
be applicable to support the engineering geological practitioner. The aim of the PGEGWP is to produce a report that will act as an essential reference handbook as well as a valuable textbook for practicing professionals and students. The style will be concise and digestible by the non-specialist, yet be authoritative, up-todate and extensively supported by data and collations of technical information. The use of jargon will be minimized and necessary specialist terms will be defined in an extensive glossary. There will be copious illustrations, many of which will be original, and many good quality photographs. The content of the report will embrace a full range of topics, from the latest research findings to practical applications of existing information. Likely directions of research and predictions of future developments will be highlighted where appropriate. The report will be based on world-wide experience in periglacial and glacial terrain and will draw upon the experience of its members and publications on periglacial and glacial conditions.

The Working Party members will be collectively responsible for the whole report. Although each participating member will be the named author or co-author of one or more chapters, all members will be expected to review and contribute to the chapters drafted by other members and would be acknowledged as such. Individual book chapters will be included in the Thomson Book Citation Index.

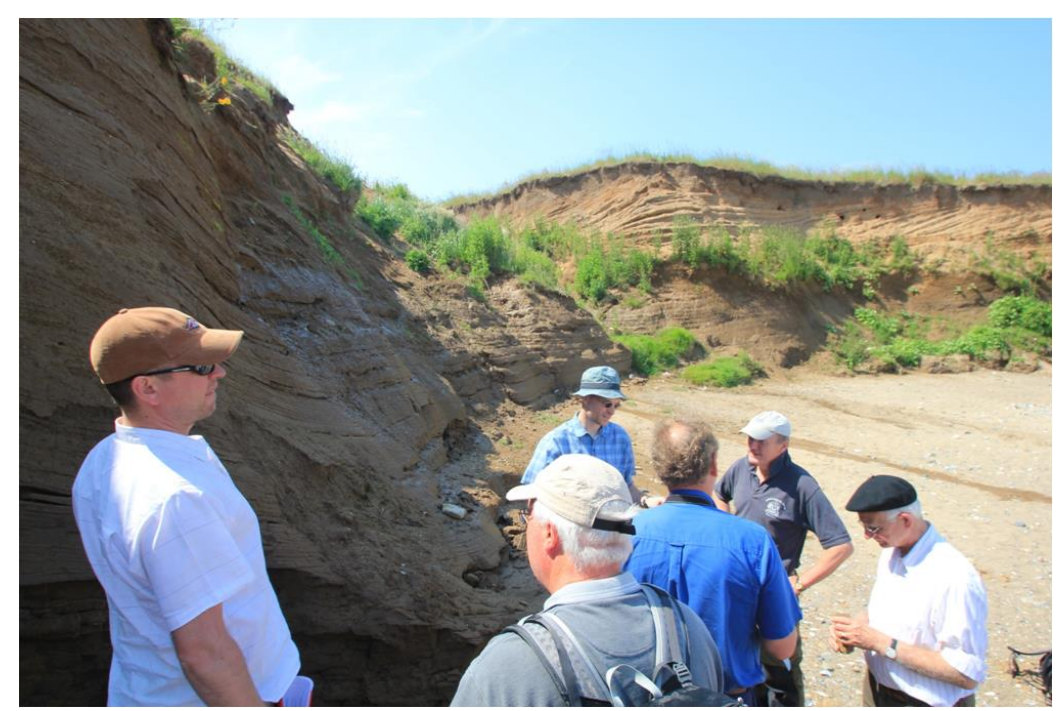

Fig. 4 Working Party field visit to North East England to discuss potential glacial sediment nomenclatures and ground models to be included in the final publication. Field description and assessment methodologies have been a core discussion point of the Working Party. 


\begin{tabular}{|c|c|}
\hline $\begin{array}{l}\text { Terrain } \\
\text { Unit }\end{array}$ & Relict Frost Mounds / Relict Ramparted Ground-Ice Depressions: Pingos \\
\hline Image & 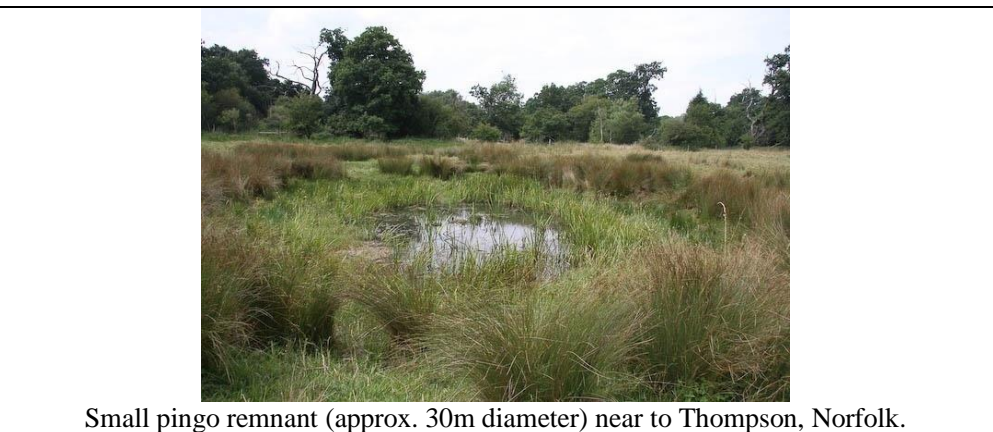 \\
\hline $\begin{array}{l}\text { Form / } \\
\text { Topography }\end{array}$ & $\begin{array}{l}\text { Pingos are ice-cored mounds or hills developed in permafrost. Relict pingos and other } \\
\text { ground ice mounds formed during Quaternary cold stages may be indicated by circular } \\
\text { or ovate depressions, often surrounded by raised rampart-like rims with a peat or soft } \\
\text { ground core. Two forms are identified, closed system (or hydrostatic) pingos and open } \\
\text { system (or hydraulic) pingos. The former occur in lowland settings within the continu- } \\
\text { ous permafrost zone, and the latter are more common in valley bottom and footslope } \\
\text { localities in both discontinuous and continuous permafrost. Pingos can reach up to } 70 \mathrm{~m} \\
\text { in height and up to } 600 \mathrm{~m} \text { in diameter. }\end{array}$ \\
\hline Landsystem & Lowland Periglacial Terrain \\
\hline $\begin{array}{l}\text { Process of } \\
\text { Formation }\end{array}$ & $\begin{array}{l}\text { Formed by injection of water into near surface permafrost to form an ice core. Water } \\
\text { under sufficient pressure to overcome overburden stress. Pressure can develop in two } \\
\text { ways; Closed System where water is expelled from saturated coarse grained sediments } \\
\text { during the refreezing of a talik (a zone of unfrozen sediment within a continuous per- } \\
\text { mafrost) or Open System where artesian water pressures within a sub permafrost aqui- } \\
\text { fer cause upward injection and freezing of water. }\end{array}$ \\
\hline $\begin{array}{l}\text { Modern } \\
\text { Analogue }\end{array}$ & Active Pingo, Innerhytte, Svalbard. \\
\hline $\begin{array}{l}\text { Associated } \\
\text { Features }\end{array}$ & $\begin{array}{l}\text { Related smaller ground ice phenomena associated with permafrost regions are lithalsas, } \\
\text { mineral palsas, and seasonal ground ice mounds. }\end{array}$ \\
\hline $\begin{array}{l}\text { Engineering } \\
\text { Significance }\end{array}$ & Compressible soils; Differential settlement \\
\hline References & Harris \& Ross $(2007)$, Hutchinson $(1980,1991,1992)$ \\
\hline
\end{tabular}

Table 1. Example of a Terrain Unit definition table from the Geomorphological Setting chapter. 


\section{Chapter Listing with Lead Authors}

The Working Party is chaired by Chris Martin, (BP) who will also draw together the diverse inputs that will be required for the introductory first chapter. Anna Morley (Arup) is the Secretary of the Working Party while Professor Jim Griffiths (University of Plymouth) is the current Editor in Chief for the Engineering Geology Special Publications series. The chapter titles and lead authors of the remaining chapters are as follows:

- Quaternary Setting

- Dr Sven Lukas, Queen Mary University of London

- Geomorphological Framework

- David Giles, University of Portsmouth

- Glacial Conceptual Ground Models

- Professor David Evans, Durham University

- Periglacial Conceptual Ground Models

- Professor Julian Murton, University of Sussex

- $\quad$ Engineering Behaviour \& Properties

- Professor Martin Culshaw, University of Birmingham

- Engineering Investigation \& Assessment

- Dr Mike de Freitas, Imperial College

- Design \& Construction Considerations

- Dr Mike Winter, Transport Research Laboratory

- Geohazards and Problematic Ground

○ Dr Laurance Donnelly, Wardell Armstrong

\section{References}

Fookes, P. G. (Ed.). (1997). Tropical Residual Soils: A Geological Society Engineering Group Working Party Revised Report. Geological Society, London, UK.

McMillan, A., \& Powell, J. (1999). BGS rock classification scheme. Volume 4, classification of artificial (man-made) ground and natural superficial deposits: applications to geological maps and datasets in the UK. British Geological Survey Research Report, RR 99-04, Keyworth, UK.

Walker, M. J. (Ed.). (2012). Hot Deserts: Engineering, Geology and Geomorphology: Engineering Group Working Party Report (No. 25). Geological Society, London, UK. 